\title{
Efficacy of Using Carbopol As An Adjuvant for Tissue Culture Inactivated Rabies Vaccine
}

\author{
Naglaa, I. Aly*; Omaima, A. E. El-Shamandy; Shendy, M.B; Fatma, F. Warda and Ekbal, \\ M. Farouk
}

Department of Pet Animal Vaccine Research, Veterinary Serum and Vaccine Research Institute (VSVRI), Agriculture Research Center, Abassia, Cairo, Egypt.

*Corresponding Author, Naglaa, Ibrahim. Aly, E-mail: naglaaaly20093@yahoo.com

\begin{abstract}
In a trail to improve rabies vaccine's immunogenicity, water-soluble acrylic acid (carbopol) was used as an adjuvant in the prepared vaccine. The potency test of the National Institute of Health revealed that the prepared vaccine is potent and efficient. Studying the dynamics of serum antibody in vaccinated dogs using serum neutralizing antibodies test and ELISA showed that antibody titer (0.9 and 1.2352 respectively) reached a level considered protective within two weeks and increased till lasted consist ant (2.4 and 2.694) during the experiment for about twenty-four weeks. In conclusion, the present study results indicated that the vaccine formulated according to this study procedure could provoke long-lasting protective immune response after a single dose administration without any adverse reaction.
\end{abstract}

Keywords: Carbopol, ELISA, inactivated Vaccine, Rabies.

\section{Original Article:}

https://dx.doi.org/10.21608/javs.2020.103

Received :23 June, 2020.

Accepted :16 July, 2020.

Published in:July, 2020.

This is an open access article under the tern of the Creative Commons Attribution $4 . \mathrm{C}$ (CC-BY) International License . To view a copy of this license,visi hthttp://creativecommons.org/licenses/by/4.0 I

J.Appl. Vet. Sci., 5(3 ): $103-107$.

\section{INTRODUCTION}

Rabies is a viral zoonotic neglected disease caused by a negative sense single-stranded RNA virus from the Genus Lyssavirus (Warrell and Warrell, 2004). It affects all warm-blooded mammals and the virus shades in the saliva of clinically ill animals and is transmitted through a bite. Once clinical symptoms appear, it is almost $100 \%$ fatal. Although a wide range of animals can become infected and transmit the disease, only mammals from the Carnivora and Chiroptera (bats) Order act as reservoirs for the disease (Lembo et al., 2010).

The important challenge of prevention and control of rabies in the world will require international efforts to increase the availability and use of high quality rabies vaccines for humans and animals (Zinsstag et al., 2007). Vaccine developments for rabies had seen different phases since 1885 when Pasteur invented his first live attenuated vaccine. Then the production of this vaccine followed the technological improvement towards immunogenicity and safeguards. Today, as recommended by the World Health Organization (WHO), rabies vaccines for humans and animals consist of inactivated viruses produced in continuous cell lines (WHO, 2007).

Adjuvants are vital components of vaccines in general; they are used to increase antigens' immunogenicity and thus increase vaccine efficacy (Coffman et al., 2010). The immune-modulating activities of polyanions were first described over 30 years ago (Diamantstein et al., 1971 and Gall $\boldsymbol{e t}$ al. .1972) and more recently, polyacrylic acid polymers termed carbopol have been evaluated as adjuvants in veterinary vaccines (Gualandi et al., 1988; Mumford et al., 1998; Tollersrud et al., 2002; Liu et al., 2005; Hoogland et al., 2006 and Mair et al., 2015). These reports suggest that carbopol is not harmful in mammals and is more effective than antigen alone. It has been shown to enhance the strength and duration of antibody responses stimulated by the inactivated vaccine (Zhang et al., 2018).

This work was conducted to study the effect of carbopol as an adjuvant in the preparation of inactivated rabies vaccine containing the whole virus on stimulating the humoral immune response in vaccinated puppies. 


\section{Efficacy of Using Carbopol as an Adjuvant ......}

\section{MATERIALS AND METHODS}

\section{Viruses}

\subsection{Cell culture adapted rabies virus}

Evelyn Rokitnicki Abelseth (ERA) strain of rabies virus adapted to BHK-21 cell line with a titer of 7.5 - $8 \log _{10} \mathrm{TCID}_{50} / \mathrm{ml}$ was supplied by the Department of Pet Animal Vaccine Research, Veterinary Serum and Vaccine Research Institute (VSVRI), Abbasia Cairo Egypt. It was used for vaccine preparation and serum neutralization tests to estimate the induced antibody titer in immunized animals.

\subsection{Challenge virus strain (CVS)}

Mice brain adapted rabies virus with a titer of $6.5 \log _{10} \mathrm{MLD}_{50} / \mathrm{ml}$ was obtained from the Department of Pet Animal Vaccine Research, VSVRI and used in the National Institutes of health potency test (NIH test) to evaluate the antigenic value of the prepared vaccine.

\section{Baby hamster kidney cell culture (BHK21)}

BHK $_{21}$ was supplied by the Department of Pet Animal Vaccine Research, (VSVRI) Abbasia Cairo, Egypt. It was used to prepare virus suspension and application of serum neutralization test (SNT) to estimate rabies neutralizing antibody titers in vaccinated dogs.

\section{Preparation of Carbopol adjuvant}

Carbopol was supplied from Lubrizol Co. as a fluffy white powder. It was dissolved in hot water to prepare $0.5 \%$ aqueous stock solutions, sterilized by autoclaving at $121^{\circ} \mathrm{C}$ for $20 \mathrm{~min}$, then stored at $4^{\circ} \mathrm{C}$ until further use (United States Pharmacopeial Convention, 1990).

\section{Preparation of vaccine}

- ERA virus strain of rabies was propagated in $\mathrm{BHK}_{21}$ cell culture and a virus suspension was prepared with a titer of $7 \log _{10} \mathrm{TCID}_{50} / \mathrm{ml}$.

- The virus suspension was inactivated with binary ethylenemine (Larghi, and Nebel, 1980).

- An equal volume of the inactivated virus was mixed with the aqueous solution of carbopol and then neutralized with $20 \%$ Sodium hydroxide.

\section{Vaccines}

\subsection{Local inactivated rabies vaccine}

Local inactivated cell culture rabies vaccine with aluminum hydroxide gel adjuvant was supplied by the Department of Pet Animal Vaccine Research, VSVRI and used to vaccinate experimental animals compared with the prepared vaccine.

\subsection{Reference rabies vaccine}

The defensor-1 rabies vaccine was supplied by Zoetis, USA and used as a reference vaccine in the potency test of the National Institute of Health (NIH).

\section{6-Experimental animals}

6.1. Mice

Two hundred and fifty Swiss Albino mice (3-4 weeks old) were used to determine rabies vaccines' antigenic value using the potency test of (NIH) and for safety tests.

\subsection{Dogs}

Fifteen native breed dogs of about 3-4 months of age were found to be free from rabies antibodies as screened by serum neutralization test. They were divided into three groups (each contains five animals) where the first group was vaccinated with the traditional locally produced inactivated rabies vaccine inoculated subcutaneously $(\mathrm{s} / \mathrm{c})$ in the inner aspect of the thigh; the second group was vaccinated with the prepared Carbopol adjuvanted rabies vaccine through the same route while 3rd group was kept nonvaccinated as control. Serum samples were obtained from animal groups weekly post-vaccination up to 6 months.

7.Quality control testing of the prepared Carbopol adjuvanted rabies vaccine

Sterility and safety testing applied to the prepared vaccine for freedom of foreign contaminants (aerobic and anaerobic bacteria, fungi and mycoplasma) and living virus (WHO, 1984). The potency of the tested vaccine was evaluated using the National Institute of Health (NIH) protocol. The vaccines were diluted fivefold. Each dilution was inoculated as $0.5 \mathrm{ml} /$ mouse (10/group). The second dose was administered on the $7^{\text {th }}$ day of prime one on $14^{\text {th }}$ day immunized mice were challenged using challenge virus standard (CVS) used as $12.5-50 \mathrm{LD}_{50}$. Mortality was recorded started from $5^{\text {th }}$ to $15^{\text {th }}$ days post-infection. Vaccine potency was calculated according to the WHO protocol (WHO, 1984 and Barth et al., 1988).

\section{Serum neutralization test (SNT)}

It was carried out to estimate rabies neutralizing antibodies in the serum of test animals (Yoneda et al., 2008). The antibody titer was determined as the final serum dilution which neutralized and inhibited the appearance of the cytopathic effect (CPE) of $100 \mathrm{TCID}_{50}$ of rabies virus (Rossiter, et al., 1985).

\section{Indirect Enzyme-linked Immunosorbent Assay (ELISA)}

Solid-phase ELISA was carried out to follow up the induced rabies antibody titers in vaccinated dogs using ELISA kit (Zoetis In., USA) according to the manufacture instructions. Positive and negative control sera were provided in the kit (Kemeny, 1991).

\section{Statistical analysis}

Data were expressed as mean. " $F$ " calculated. One-way ANOVA was used to compare the parameters between groups. P- Values of $>0.05$ were considered statistically significant. 


\section{RESULTS}

\section{Quality Control of prepared vaccine Sterility}

The prepared vaccine gave satisfactory results. It was free from mycoplasma, aerobic,anaerobic bacteria and fungi.

\section{Safety test}

No rise in body temperature with no postvaccinal reaction and any abnormal signs in inoculated mice with double doses.

Potency test of the prepared vaccines in mice (NIH) The antigenic value of the locally prepared aluminum hydroxide gel rabies vaccine and carbopol adjuvanted rabies vaccine was ( 2.3 and 2.5 respectively) which is measured by the NIH test appear to be higher than the recommended values of inactivated rabies vaccine which should not be less than 0.3 .

The humoral immune response of vaccinated dogs The result of detection the neutralizing antibody in the sera of vaccinated dogs by SNT \& ELISA is tabulated in the table (1\&2).

By statistical analysis using ANOVA test for the results representing in the table (1), it was found that the calculated (F) was 7.042283 while the tabulated (F) was 1.833113 , i.e., there is a significant difference at $\mathrm{P}>0.05$ between group vaccinated with aluminum hydroxide gel rabies vaccine and group vaccinated with Carbopol Adjuvanted Vaccine

Table 1: Mean Rabies serum neutralizing antibody titer in vaccinated dogs

\begin{tabular}{|cccc|}
\hline \multirow{3}{*}{$\begin{array}{c}\text { Meeks } \\
\text { post } \\
\text { Vaccination }\end{array}$} & $\begin{array}{c}\text { Merum neutralizing antibody titer } \\
\left(\log _{10}\right)\end{array}$ \\
\cline { 2 - 4 } & $\begin{array}{c}\text { Aluminum } \\
\text { hydroxide } \\
\text { gel vaccine }\end{array}$ & $\begin{array}{c}\text { Carbopol } \\
\text { Adjuvanted } \\
\text { Vaccine }\end{array}$ & $\begin{array}{c}\text { Unvaccinated } \\
\text { control }\end{array}$ \\
\hline 0 & 0 & 0 & 0 \\
\hline 1 & $>0.3$ & 0.7 & 0 \\
\hline 2 & 0.6 & 0.9 & 0 \\
\hline 3 & 1.2 & 1.5 & 0 \\
\hline 4 & 1.5 & 2.1 & 0 \\
\hline 8 & 1.8 & 2.4 & 0 \\
\hline 12 & 1.8 & 2.4 & 0 \\
\hline 16 & 1.8 & 2.4 & 0 \\
\hline 20 & 1.8 & 2.4 & 0 \\
\hline 24 & 1.8 & 2.4 & 0 \\
\hline
\end{tabular}

By statistical analysis using ANOVA test for the results representing in the table (2), it was found that the calculated (F) was 8.271514 while the tabulated (F) was 1.833113 , i.e., there is a significant difference at $\mathrm{P}>0.05$ between group vaccinated with aluminum hydroxide gel rabies vaccine and group vaccinated with Carbopol Adjuvanted Vaccine.

Table2: Rabies ELISA optic density in vaccinated dogs

\begin{tabular}{|c|c|c|c|}
\hline \multirow[b]{2}{*}{$\begin{array}{c}\text { Weeks } \\
\text { post } \\
\text { Vaccination }\end{array}$} & \multicolumn{3}{|c|}{ Rabies ELISA optic density } \\
\hline & $\begin{array}{l}\text { Aluminum } \\
\text { hydroxide } \\
\text { gel vaccine }\end{array}$ & $\begin{array}{c}\text { Carbopol } \\
\text { Adjuvanted } \\
\text { Vaccine }\end{array}$ & $\begin{array}{l}\text { Unvaccinated } \\
\text { control }\end{array}$ \\
\hline 0 & 0.2035 & 0.2021 & 0.1945 \\
\hline 1 & 0.6412 & 0.9642 & 0.2163 \\
\hline 2 & 0.8381 & 1.2352 & 1.4614 \\
\hline 3 & 1.4614 & 1.8322 & 0.1899 \\
\hline 4 & 1.8231 & 2.1663 & 0.1945 \\
\hline 8 & 2.2102 & 2.6957 & 0.1988 \\
\hline 12 & 2.2025 & 2.6862 & 0.2163 \\
\hline 16 & 2.2402 & 2.6712 & 0.2110 \\
\hline 20 & 2.2515 & 2.6949 & 0.2243 \\
\hline 24 & 2.2422 & 2.6771 & 0.2241 \\
\hline
\end{tabular}

\section{DISCUSSION}

Canine rabies continues to be a major threat in many countries especially in Asia and in Africa. To control rabies in dogs, vaccination is the key strategy (Knobel et al. 2005). Many factors critically influence vaccine potency during its formulation. The criteria in selecting this formulation should consider the properties of the antigenic components, the required immune response, route of delivery, avoiding significant side effects as well as vaccine stability. The evaluation of rabies vaccine potency is of great importance, as the antigenicity of vaccine is generally determined in vivo by the NIH (National Institute of Health) test, the antigenic value of the locally prepared aluminum hydroxide gel rabies vaccine and carbopol adjuvanted rabies vaccine was $(2.3$ and 2.5 respectively) which appear to be higher than the recommended values of inactivated rabies vaccine which should not be less than 0.3 (WHO, 1984 and Barth et al., 1988). 
An adjuvant is a chemical substance added during the formulation of the vaccine to elevate the immune response. Ideal adjuvant should be safe, stable, biodegradable, inexpensive, and capable of stimulating an antigen-specific immune response and ensuring the vaccine potency's reproducibility during manufacturing (Carter and Reed, 2010).

Using carbopol in animal models results in systemic adjuvant activity, including strong proinflammatory type1 T-cell (Th1) polarization. (Schwabe et al., 1977). It has been evaluated as adjuvants in different veterinary vaccines (Gualandi $\boldsymbol{e t}$ al., 1988; Mumford et al., 1998; Vereecken et al., 2000; Tollersrud et al., 2002; Liu et al., 2005; Hoogland et al., 2006; Minke et al., 2007; Jacqueline et al., 2010 and Mair et al., 2015).

The immunogenicity of vaccines is a key factor in judging vaccines' effectiveness and usually reflects by the titer of antibody-induced following inoculation. The result of measuring the neutralizing antibody in the sera of vaccinated dogs by SNT \& ELISA is tabulated in the table $(1 \& 2)$ revealed that the two tested vaccines induced detectable serum neutralizing and ELISA rabies antibodies in vaccinated dogs by the secondweek post-vaccination reaching its peak levels by the $8^{\text {th }}$ week and nearly remained unchanged up to 4 months later. Such antibodies recorded their mean peak titers post-vaccination of dogs with either vaccine to be 1.8 and 2.4 by SNT and 2.2102 and 2.6957 by ELISA in the vaccinated group with aluminum hydroxide gel vaccine and Carbopol adjuvanted rabies vaccine respectively.

It is important to point out that both aluminum hydroxide gel and Carbopol are promising adjuvants of significant immune-enhancing potentials based on the elevation of the humoral immune response. Despite these results, it was clear that from the statistical analysis using ANOVA test, carbopol has the potential to elicit higher levels of humoral antibody, more rapid onset of immunity and enhanced protection as compared with conventional aluminum hydroxide gel, adjuvants. Where Carbopol administration triggered rapid and robust leukocyte recruitment, proinflammatory cytokine secretion and antigen capture largely by inflammatory monocytes in addition to direct B-cell activation, possibly serving as an antigen delivery system (Krashias $\boldsymbol{e t}$ al., 2010 \& Gartlana $\boldsymbol{e t}$ al., 2016).

Depending on the obtained results, it could be concluded that the carbopol adjuvanted rabies vaccines are preferable than aluminum hydroxide gel vaccine providing high protective levels in vaccinated dogs. Other advantages of carbopol include the fact that there is no evidence of local or systemic reactions. The antigen can be mixed with the carbopol gel by merely shaking, and it does not separate upon storage.

\section{REFERENCES}

BARTH R, DIDERRICH G AND WEINMANN E .1988. NIH test, a problematic method for testing potency of inactivated rabies vaccine. Vaccine Volume 6, Issue 4, Pages 369-377.

CARTER D, AND REED SG, 2010. Role of adjuvants in modeling the immune response. Current Opinion in HIV and AIDS. 5: 409-513.

COFFMAN RL, SHER A AND SEDER RA. 2010. Vaccine adjuvants: putting innate immunity to work. Immunity 33(4):492-503.

DIAMANTSTEIN T, WAGNER B, BEYSE I, ODENWALD MV, AND SCHULZ G. I. 1971. Stimulation of humoral antibody formation by polyanions. The effect of polyacrylic acid on the primary immune response in mice immunized with sheep red blood cells. Eur J Immunol 1: 335-40.

GALL D, KNIGHT PA AND HAMPSON F. 1972. Adjuvant activity of polyelectrolytes. Immunology, 23:569-75.

GARTLAN H. KATE, GEORGE KRASHIAS, FRANK WEGMANN, WILLIAM R. HILLSON, ERIN M. SCHERER, PHILIP D. GREENBERG, STEPHANIE C. EISENBARTH, AMIN E. MOGHADDAM AND QUENTIN J. SATTENTAU 2016. Sterile inflammation induced by Carbopol elicits robust adaptive immune responses in the absence of pathogen-associated molecular patterns. Vaccine, 34: 2188-2196.

GUALANDI GL, LOSIO NM, MURATORI G AND FONI E. 1988. The different ability preparations of porcine parvovirus to enhance humoral immunity in swine and guinea pigs. Microbiological, 11:363-9.

HOOGLAND MJ, OPRIESSNIG T AND HALBUR PG. 2006. Effects of adjuvants on porcine circovirus type 2associated lesions. J Swine Health Prod, 14:133-9.

JACQUELINE GELFI, MICHAEL PAPPALARDO, CARINE CLAVERYS, BRIGITTE PERALTA AND JEAN-LUC GUERIN. 2010. Safety and efficacy of an inactivated Carbopol adjuvanted goose haemorrhagic polyomavirus vaccine for domestic geese. Avian Pathology, 39 (2), 111-116.

KEMENY, D.M. 1991. A practical guide to ELISA.. Pergmon Press Oxford $1^{\text {st }}$ Ed, 115pp.

KNOBEL DL, CLEAVELAND S, COLEMAN PG, 2005. Re-evaluating the burden of rabies in Africa and Asia. Bull World Health Organ;83:360-8.

KRASHIAS G, SIMON AK, WEGMANN F, KOK WL, HO LP, AND STEVENS D. 2010. Potent adaptive immune responses induced against HIV-1 gp140 and influenza virus HA by a polyanionic carbomer. Vaccine, 28(13):2482-2489.

LARGHI, O.P. AND A.E. NEBEL 1980. Rabies virus inactivation by binary ethylenimine: New method for inactivated vaccine production. J.Clic.Microbiol, vol.2, pp.120-122.

LEMBO T, HAMPSON K, KAARE MT, ERNEST E, KNOBEL D AND KAZWALA RR. 2010. The 
Feasibility of Canine Rabies Elimination in Africa: Dispelling Doubts with Data. Plos.Negl. Trop.Dis, 4: E626.

LIU IKM, TURNER JR JW, VAN LEEUWEN EMG, FLANAGAN DR, HEDRICK JL, MURATA K, LANE VM AND MORALES-LEVY MP. 2005. Persistence of anti-zonae pellucidae antibodies following a single inoculation of porcine zonae pellucidae in the domestic equine. Reproduction, 129:181-90.

MAIR KH, KOINIG H, GERNER W, HOHNE A, BRETTHAUER J AND KROLL JJ. 2015. Carbopol improves the early cellular immune responses induced by the modified-life vaccine. Ingelvac $\operatorname{PRRS}((\mathrm{R}))$ MLV. Vet. Microbiol, 176:352-7.

MINKE, J.M., TOULEMONDE, C.E., DINIC, S., COZETTE, V., CULLINANE, A AND AUDONNET, J.C. 2007. Effective priming of foals born to immune dams against influenza by a canary pox-vectored recombinant influenza $\mathrm{H} 3 \mathrm{~N} 8$ vaccine. Journal of Comparative Pathology, 137(Suppl 1), S76 80.

MUMFORD JA, WILSON H, HANNANT D AND JESSETT DM. 1998. Antigenicity and immunogenicity of equine influenza vaccines containing a Carbomer adjuvant. Epidemiologic Infect, (1973): 112:421-37.

ROSSITER, P.B., JESSETT, D.M. AND TAYLOR, W.P. 1985. Microneutralization system for use with different strains of peste des petits ruminant's virus. Top. Anim. Hith. Prod., 17(2): 75-81.

SCHWABE, C.W., RIEMANN, H. AND FRANTI, F. 1977. Epidemiology in veterinary practice. 1 st Ed. Lee and Febiger, Philadelphia

TOLLERSRUD T, NORSTEBO PE, ENGVIK JP, ANDERSEN SR, REITAN LJ AND LUND A. 2002. Antibody responses in sheep vaccinated against Staphylococcus aureus mastitis: a comparison of two experimental vaccines containing different adjuvants. Vet Res Commun, 26:587 - 600.

UNITED STATES PHARMACOPEIAL CONVENTION. 1990. Carbomer. Inc. Rockville, Maryland, 1911.

VEREECKEN M., DE HERDT P., DUCATELLE R. AND HAESEBROUCK, F. 2000. The effect of vaccination on the course of an experimental Salmonella Typhimurium infection in racing pigeons. Avian Pathology, 29, 465- 471.

WARRELL MJ AND WARRELL DA. 2004. Rabies and Other Lyssa Virus Diseases. Lancet. 363: 959-969.

WHO EXPERT COMMITTEE ON RABIES 1992. Tech Report Series, 8th Report, No 824. Geneva, WHO, 55.

WORLD HEALTH ORGANIZATION. 2007. IT'S Position Paper on Rabies Vaccines, Weekly Epidemiologic Record, Vol. 82, No. 49-50, pp. 425436.

WORLD HEALTH ORGANIZATION. 1984. Report of WHO Consultation on Rabies. WHO Tech. Rep. Ser. N 709.

YONEDA, A., K. TUCHIYA, Y. TAKASHIMA, T. ARAKAWA, N. TSUJI, Y. HAYASHI AND Y. MATSUMOTO. 2008. Protection of mice from rabies by intranasal immunization with inactivated rabies virus. Exp. Anim., vol.57: (1), pp.1-9.

ZHANG J., WANG M., ZHOU N., SHEN Y. AND LI, Y. 2018. Evaluation of carbopol as an adjuvant on the effectiveness of progressive atrophic rhinitis vaccine. Vaccine, 16; 36 (30):4477-4484.

ZINSSTAG J, SCHELLING E, ROTH F, BONFOH B. AND SAVIGNY, D. 2007. Human Benefits of Animal Interventions for Zoonosis Control. Emerg. Infect. Dis, 13: 527- 531 .

How to cite this article:

Naglaa I. Aly, Omaima A. El-Shamandy, Shendy, M.B; Fatma F. Warda; and Ekbal, M. Farouk. 2020. Efficacy Of Using Carbopol As An Adjuvant For Tissue Culture Inactivated Rabies Vaccine. Journal of Applied Veterinary Sciences, 5(3): 103 - 107.

DOI: https://dx.doi.org/10.21608/javs.2020.103395 